\title{
The Self as Data: A Qualitative Methodology
}

\author{
Josie Arnold \\ Swinburne University of Technology \\ Locked Bag 218Lilydale, Victoria 3140, Australia \\ E-mail: jarnold@swin.edu.au
}

Received: September 6, 2011

Accepted: November 18, $2011 \quad$ Published: December 30, 2011

doi:10.5539/jedp.v1n1p65

URL: http://dx.doi.org/10.5539/jedp.v1n1p65

\begin{abstract}
This paper explores ways in which recognition and involvement of the story of self means that the "I" becomes data and methodology. I also look at the ways in which such a narrative of knowledge can legitimately add to the scholarly conversations within the academy. Increasingly, qualitative methodologies in the academy are looking towards newer and more diverse understandings of the ways in which we explore ourselves in the process of exploring ideas, practices, and scholarly questions so as to take an academic debate forward. This means that the self as data has become a mine for exploration and increasing knowledge-production as a result of analytic observation through the prism of self. It does not mean that there is a simple reductionist view of one's own observations as being significant in themselves alone. Rather, it is a recognition of the inevitability of the "I" being involved in academic knowledge production.
\end{abstract}

Keywords: Academic narratives, Knowledge production, Self as data

\section{The Exploration of Self as an Inevitable Attribute of Knowledge Construction}

As in every field of communication, there are very specific discourse conventions regarding situating academic work within the current academic debates. Such academic discourse is a significant aspect of research dialogues and these dialogues may vary from subject area to subject area and from time to time. Whatever the subject area or time, however, this is what Andrew Northedge calls entering into: “...high status discourse communities, which have successfully established claims to 'expertise' within the wider society..." so that knowledge "....arises out of a process of discoursing..." and "...to be knowledgeable is to be capable of participating in the specialist discourse..." (2003:19-20 his italics) Today, such academic literacies exist as generative aspects of complex thinking rather than as merely conveying information or commenting upon others' complex thinking. At the same time, they are a meta-discourse of a particular academic community and the aim is to enable expert readers who can successfully and fruitfully "navigate the text' (Dahl 2004:1812) within their own discourse communities.

The more intransigent and confining aspects of such "academic literacies" are continually under challenge from qualitative methodologies. For example, once it was thought that the very word "I", much less the concept of self as data, should never appear in a scholarly tract. Qualitative critical frameworks and methodologies have challenged this type of "given". Yet a closed and prescriptive academic discourse model has been basic in scholarly communities generally and in some more than others. Barbara Kamler \& Pat Thomson describe this as scholars : "...positioning themselves to be seen as legitimate knowers within particular scholarly communities" (2004: 197) As I go on to discuss, auto-ethnographic practices seem to me fruitfully to dispute the closed nature of such scholarly conventions within discrete communities of knowledge.

In rejecting the dominance of such "academic literacies" and "scholarly conventions", Nicholas Holt discusses "the use of self as the only data source" in relationship to feedback from 7 reviewers so as to develop "appropriate evaluative criteria for such work". He bases his discussion on the assertion that "the postmodern research movement has raised doubts about the privilege of any one method for obtaining authoritative knowledge about the social world." (2003:18). He identifies that there is a continuing application of outmoded concepts and practices of "academic literacies" to self as data by referees in the academic publication process. Holt sees this as misplaced.

\subsection{Auto-ethnography}

In a similar vein, Philippe Bougois discusses "the reproduction of academic habitus" in relationship to 
ethnography and in doing so accepts that postmodernist critique has been beneficial for ethnography. It has debunked the naively positivist enlightenment project of mainstream social sciences and humanities and has unsettled the essentializing tendencies of anthropology's culture concept which so easily slide into another version of racism and postcolonial domination. The recognized illegitimacy of the omniscient ethnographer now forces even positivist ethnographers to locate themselves within their texts and to recognize that reality is socially constructed-if not fragmented, dialogical, and contested. (2002:418)

If this is so for ethnographers, then it is also apposite for auto-ethnography that has grown from that discipline.

\subsection{Subjective Academic Narratives}

It is in this spirit that I bring to this discussion of utilising the data of self my own personal observations and reactions as well as my academic reading and thinking. This concept follows upon my meeting with Gregory Ulmer's idea of a "my story" when I was doing my own $\mathrm{PhD}$ in 1990. I have referred to this extensively in my own writing. Briefly, Ulmer proposes that there is in academic writing the self and the researched, the conscious intellectual semiotic and that arising from storytelling. "My story" encompasses the self, the story and the mystery of this and puts under erasure all claims to fact in writing, revealing the academic text to be sewn together as a compilation of the scholarly, the anecdotal or popular, and the autobiographical. This paper displays how the mystorical approach enables academic writing and language to be open, explorative and aware of its own impermanent nature.

Postmodernist theories about textuality and discourse advance the thinking about (and practice of) linear analytico-referential knowledge-model being overtaken by lateral postmodernist discourse. Such a conceptual framework involves Ulmer's "my story" and the pastiche of the dispersal of certainties in considering the practice of writing a discursive piece on a given topic that adds to academic knowledge. Terms such as decoupage, pastiche and montage have begun to be widely applied to ways of thinking. This is to emphasise that traditional Western scientific, logical and hence linear ways of attaining insights, knowledge and even wisdom are rather more spurious than conventional wisdom would have them be. This is because they implicate thinkers in the act of putting together ideas as a painstaking construction that attempts to construct an unreachable yet highly desirable "reality".

Such methodology asserts that one academic's experience provides a relevant basis for academic writing in conversation with other scholars. It indicates that the purely personal can be acceptably utilised as evidence of an academic contribution to knowledge. In a postmodernist dispersal of certainties, I am prepared to assert that I can do so by practising what I have called "the subjective academic narrative" and written about "the subjective academic narrative". (Arnold: 2010) This has some congruence with the practice of auto-ethnography as a research methodology: auto (self), ethno (culture) and grapho (the research process). (Chang 2008:48)

\subsection{The Literature Review}

Traditionally, the academic discourse has been one modelled upon peer interactions within a very clearly defined model of research writing. The most significant underpinning of this discourse has been the review of relevant academic literature that situates the discussion being put forward within the published area and particularly blind-reviewed peer journal publications. Indeed, this aspect of the academic discourse is well described by David Boote and Penny Beile (2005:3) who state that "a thorough, sophisticated literature review is the foundation and inspiration for substantial, useful research." This continues to be a central plank of my "subjective academic narrative model", as the research discourse cannot be engaged with by a lone person. Dialogue with, between and amongst other academics looking at narratives in research is an integral part of such a methodology. This indicates how such qualitative methodologies are not some "soft option". Rather they give credence to a reality: we are involved as ourselves within our academic discourse.

This means for me that we are utilising the power of the unsolved paradox between the descriptor: "subjective academic narrative" that I employ. For at the same time as emphasising the centrality of the self as data, I also acknowledge the importance of entering into a lively discourse with other academics through citing the literature. As I situate myself within this academic discourse, I admit myself to the discussion as an active player.

\section{Self-reflection, Observation and Analysis as Knowledge}

The presence of the self-conscious subjective self opens up the text to many possible readings: there is no "one way". Thus even the act of writing, much less the lived experience of being, displays itself as non-authoritative in the conventional sense. The implications of this are many. For me, perhaps the most important-and the most galvanising-is that the academic life and academic writing and language are now able to be seen as open, explorative and aware of their own evanescent nature in the same way as any other form of written or lived 
discourse. That is, academic writing can be understood as related to and made up of multiple ways of respecting various personal experiences.

Self observation as knowledge also enjoys many of the elements of "narrative non-fiction" or the "literature of fact", a new and enticing genre that challenges and even eliminates paradigmatic expectations of factual writing. A methodological model such as Ulmer's "my story" or auto-ethnography gives me room within the academy to speak in multiple "voices" from multiple personal and professional experiences and areas of knowledge. It confronts the expectations of the establishment/academy, and in doing so brings forward a richer mix after the lessening of the "qualitative/quantitative" binary and the "academic corset" model. When "reality" and "knowledge" are revealed as constructions not unlike fiction, new possibilities of/for multi-linearity may emerge. (Arnold 1994)

\subsection{Academic Discourse Communities}

Barbara Myerhoff is concerned with people making sense of themselves for themselves and hence for others. (Swartz 2009:793) This challenges "givens" and cultural meta-narratives as it enables self-reflection. It highlights that "the stories we tell about ourselves, the roles we play, the artifacts we construct, and the relationships we negotiate continually generate and revise who we are." (Swartz 2009:794) Ronnie Swartz goes on to identify that this self-reflection is enhanced by others "reflecting back". This allows people to both tell their stories and to construct them further relationally. Swartz says that, because of this understanding, "Myerhoff explicitly allows for the contradictions, paradoxes and fantasies that imbue stories of identity" (as they do, I believe, in all stories). Personal identity cannot be clean, consistent, or concise, nor can it ever be fixed and permanent, nor yet can it be individually bounded. (Swartz 2009:794) He warns against "expertising" (my neologism) identity and hence becoming "at risk of stepping into non-preferred identities when an audience of identity experts is thrust upon us". (796) Academic discourse modes themselves are clearly a form of "expertising" lived personal stories.

In her discussion of academic discourse communities and cultural identities in academic prose, Trine Dahl states that "academic writers leave traces of themselves in their writing which may be linked to national as well as disciplinary culture." (2004:1807) Moreover, her study identifies an interesting aspect of scientific textuality that is not surprising but is relevant to this paper: "Since medical reporting is so formally organised, the content presented is forced into information categories in a given sequence, and no extra processing effort is needed for the expert reader to orient himself or herself within the text...to maintain a sharp distinction between research data and their interpretation" (2004:1819) No room here for a mystorical approach then, as Dahl notes that the medical text is "... a disciplinary mode that transcends national culture" (2004: 1825)

\subsection{Standards for Self-research}

In their paper setting out guidelines for teachers regarding self-study research, Robert Bullough Jr., \& Stefinee Pinnegar note that "Many researchers now accept that they are not disinterested but are deeply invested in their studies, personally and profoundly" (2001:13) They note that this approach is "quite different from those typically valued by the academy". (2001:14) Teacher-academics, in particular are at the node between practicum and research wherein an important relationship exists "between personal growth and understanding and public discourse about that understanding" (2001:15) That is, the personal and the research question are linked. They state that "when the issue confronted by the self is shown to have relationship to and bearing on the context and ethos of a time, then self-study moves to research" (2001:15) Although they are particularly referencing teacher-research, this is, in my opinion, an unnecessary narrowing of the possibilities of the self as data as research. This is particularly so in practice led research.

Bullough and Pinnegar's paper is concerned with setting standards for self-research: "perhaps the questions asked lack significance and fail to engage reviewer imagination and the questions answered are not found compelling, are purely personal, or are not answered in compelling ways". (2001:15) They identify that conventions have not been established for such academic discourse as self-study research. However, it is difficult to see how conventions that preclude the innate difference of the subjective self and their "mystory" can also record that particular and personal difference.

Convention-setting seems to have an internal contradiction when they go on to say that in self-study research: what counts as data expands greatly, and researchers face the difficulty of representing, presenting, legitimating, analysing, and reporting one's own experience as data-and doing so in honest, not self-serving ways...Self-study researchers inevitably face the added burden of establishing the virtuosity of their scholarship within and through the writing itself; lacking established authority each researcher must prove herself as a methodologist and writer. (Bullough and Pinnegar 2001:15) 
We seem to approach a "mystory" and my proposed "subjective academic narrative" more closely here?

\section{The Story of Self within the Research}

Whilst it may well seem self-evident that the self is an intrinsic enactor and definer, and personally present in every aspect of research, this is not always, or even generally, accepted. The sciences, for example, have an established methodology that until quite recently assumed that a detached report containing only what appeared to be data observed under conditions that excluded the personal was not only possible, but was essential.

In an age that ascribes to what Mary Midgley (2004) describes as the "myth" of the impersonality of scientific knowledge that we thrive upon, it is apposite to remind ourselves that all research writing is in significant part "the literature of self". Midgely enables us to see that if we can accept this about science, it will allay the fears of many who see it as a dominant paternalistic ideology against which other research is measured and fails. This leads to a faulty binary based upon fear of dominant paternalistic quantitative methodologies. Midgely advises us thus:

People who fear science today are chiefly disturbed by the way in which these imperialistic ideologies import irrelevant, inhuman standards into non-scientific aspects of life and lead people to neglect the relevant ones. Throughout the social sciences and often in the humanities too, distorted ideas of what it means to be "scientific" and "objective" still direct a great deal of life and of research. (2004:21)

However, even if there is the reality that scientific writing involves "the literature of self", this is not how it is read by traditionalists.

\subsection{Narrative Research}

Whilst the self is always involved in academic work, the explicit description, analysis and interpretation of self is not a traditional element of research methodology: it has become so due to the advancement of the subjective self in the postmodernist moment. We may refer, for example, to Roland Barthes's assertion that "the author as god is dead"; to Jacques Derrida's application of the "readerly-writer" and to Deleuze and Guattari seeing the creeping fescue (a type of grass) of the academic text rather than the root tree of knowledge.

Bullough and Pinnegar state that 'narrative research traditions are diverse and encompass methods developed in folklore, psychology, literature, history, anthropology and education. Differences arise in data collection, analysis, and presentation among those approaches. (2001:16) They then ask a very interesting and even provocative question: "what, after all, makes a self-study worth reading?" I might add to that question another that is just as pertinent: "what, after all, makes a self-study a significant contribution to academic knowledge?"

I am arguing that the quantitative model of scientific research and data is neither omnicompetent or ubiquitous: it is one narrative non-fiction amongst many. Angel Laureiro (2000) discusses how the literature of self was one of the earliest forms of writing, how it contains the illusion of self-knowledge and how autobiographical truth is from oneself: it is neither external nor verifiable. It is about the unrecoverable but imaginable past, and "...no single discourse can be privileged in the unveiling of the multiplicities that conjoin to form the subject nor should any of the discourses be deemed fictional..." (2001:13)

\subsection{Some Dynamic Possibilities of Narrative Research}

The strain caused by the apparent depersonalisation that is claimed as a significant element of quantitative methodologies is more clearly inappropriate for many qualitative methodologies, although I believe it is inappropriate for both. However, the ethical questions presented in narratives that acknowledge their own narrativity are quite different from those that arise in narratives that assume a scientific methodology. How can the University address these questions? William Smythe and Maureen Murray say that "true anonymity is a problematic requirement to meet whenever a person's story is presented and analysed as a whole and in detail". (2000:319) While they are considering the narratives of the subjects, it is also true of the storyteller. Indeed, who does own the story? For them:

Narrative discourse is structured more temporally than conceptually, concerns relations among particulars rather than abstract generalities, addresses the vicissitudes of human intentions and motivations, and aims to be convincing more by virtue of its believability than in terms of its logical coherence or empirical testability...narrative accounts are told from multiple perspectives ...narrative meaning is multiple as well. (2000:323)

Since the middle of the $20^{\text {th }}$ century, methodologies have arisen that propose alternative models to the scientific model that underpins traditional quantitative research. Although much debate has occurred, and much movement has resulted, this old "qualitative" and "quantitative" debate/dilemma is still alive in relationship to ethics 
determinations, as we can see even from the form itself which is skewed to traditional quantitative research models. The story of self, however, inevitably involves others. The University is responsible for seeing that there is an ethics clearance even for one's own observations. For example, The National Statement on Ethical Conduct in Human Research issued by the Australian government in 2007 states that an ethics clearance must be sought for observation.

Observation involves the researcher observing participant/s in their own environment, or in the environment being studied. Data collection through observation can be structured or unstructured, with the observer as acollaborative participant (participant observation) or external to the environment. (2007:26)

\section{Who Owns the Story?}

For the academy, then, who owns one's own story? Obviously not oneself alone: inevitably, the self as data involves those observed or relevant to one' own story.

The self as data has a huge impact upon traditional ways of viewing research that Mary Midgely describes as "conceptual monoculture" (2004:47) and states that "the right way to remedy the Cartesian split is not for one half of the world to swallow the other." (2004:59). An example of this comes from Janet Bryant and Barbara Lasky who describe the creative impact of a "story" upon her grounded theory methodology: "Things were generally moving in a predictable fashion. Suddenly a 'story' presented by one participant was so compelling and original that just to 'code' the interview transcript would have seemed a travesty." (Bryant and Lasky 2007:182)

Jacques Derrida's work has much to make us think about when we consider it in relationship to the qualitative methodology of auto-ethnography. It is Derrida's practical and theoretical challenges to the certainties of modernism that provide us with ways into understanding knowledge as a textual construction that needs no authoritative positioning for either writer and reader. It is his understanding that not only may boundaries be overcome, but that they are irrelevant ideological constructions residing in patriarchal notions of the authoritative that enable us to understand something of the freedoms provided by the writerly-reader. Perhaps this is most simply seen in that dynamic and anti-establishment site of Wikepedia, again distrusted by academics.

For Derrida, who espouses it, the purpose of the "exorbitant" in academic theorizing is revealed by the word's own etymology. It comes from the latin "ex" meaning "out of or from" and the "orba" meaning the "usual route". Hence the "exorbitant" is not boundried and held in submission by the usual. It is something that pushes the boundaries of the known to enable extension. (in Gallop 2002: 9)

Derrida (1978) indicates that reading leaves the orbit of the text to the reader: it is not confined by the author's thinking. In discussing "The Law of Genre" (1980), he disrupts authority further: "as soon as the word 'genre' is sounded, as soon as it is heard, as soon as one attempts to conceive it, a limit is drawn. And when a limit is established, norms and interdictions are not far behind..." (56-57). Derrida's work has led not only to a consideration of the construction of culture, but also to the possibilities involved in deconstructing cultural norms so as to identify their essential constructedness and deny their truth claims.

Jacques Derrida indicates that everything in a culture is a construction and can be most fruitfully understood when it is "read against" or "deconstructed" to show its constituent parts. His work is extremely influential in opening up challenges to societal and cultural "givens" and "norms". In this context, the influence of Derrida can be seen in the problematisation of certainties and traditional academic discourses. (Derrida, 1978).

\subsection{After the Author as God is Dead}

Roland Barthes (1977) confronted the authority of the writer and disrupted the accepted mode of authorship to famously declare that the author as god was dead and that no text of any kind could come to life without the active interpretations of individual readers coming from particular times, places and cultural environs. From this we have the interesting paradox of the "writerly-reader", the person who co-authors the text by bringing it to life through the act of reading. Clearly this is not constrained by being applicable only to the written/verbal text. When textuality is seen in all productions and even in reading nature itself, the enhancement of the readers' authority over that of the author is important and maybe even implacable?

Barthes challenges the power of the authoritative as a premature limit to interpretation rather than offering an open-ness of discourse. He proposes that the narrow interpretations of "the author as god" become more fruitful when the reader displaces this certified reading and rises from the passive to the active. There are important implications in his assertion that "The text is a tissue of quotations drawn from innumerable centres of culture." (1997: 142-3). 
There is value in the suspension of certainties and the acceptance of the text as a tissue or net in which interstices may lead to explorations that are as valuable as the threads. Helene Cixous, for example, challenges the authoritative text. She describes writing itself as "...the very possibility of change, the space that can serve as a springboard for subversive thought, the precursory movement of social and cultural structures." (Cixous, 1991: 319-320). This accords with my reading of Gregory Ulmer's (1989) "mystorical" approach opens up the text to many possible readings: there is no 'one way'. Thus even the act of writing, much less the lived experience of being, displays itself as non-authoritative in the conventional sense.

\section{Cultural Assumption in Research Writing}

Auto-ethnography is a research method that is applied by academics in their writing to demonstrate that their autobiographical personal experiences in their research can be analysed and interpreted so as to unpeel and unpack their cultural assumptions (Chang 2008:9) Its beginnings can be traced to anthropologists who immersed themselves in their own data and saw their interpretations, responses and interactions as personal and involved rather than impersonal and detached.

This recognises the impossibility of seeing ourselves as academics as either independent or unaligned. We come from a cultural discourse and we participate in that discourse. This is as true for the sciences as for the social sciences. We undertake research in an area and/or pursue a certain line of investigation and research question because of our Eurowestern understandings, particularly those of the Enlightenment period. Disrupting the givens of such a discourse has been the object of much academic thinking since the middle of the $20^{\text {th }}$ century.

Such thinking is also important in postcolonial representations of the "other" of what Gayatri Spivak calls Euroamerican domination of colonised countries that impacts still even today. In her search of archives made by the Raj, she identifies that "...the willed autobiography of the West masquerades as disinterested history..." (2000:208)

The self-narrative in auto-ethnography involves more than storytelling: it leads to and involves the analysis of such storytelling and enquiry into self as data rather than mere presentation of one's story. Auto-ethnography as a methodology utilised and valued in the academy takes self-narrative from the arena of storytelling into that of the production of data leading to new knowledge and/or new understanding of areas of known knowledge.

Chang states that: "Stemming from the field of anthropology, auto-ethnography shares the storytelling feature with other genres of self-narrative but transcends mere narration of self to engage in cultural analysis and interpretation." (92008:43). Unpeeling and unpacking the private self and the ways in which the private self has produced data through interactions, observations, analyses and interpretations provides us with insights into the modes of thought a, action and interaction that underpin and/or evolve from enacting the self as data. As Chang (2008:50-51) expresses it: “...auto-ethnographers enter the research field with a familiar topic (self) ....all aspects of life can become a subject of auto-ethnography." As a methodology, she sees it as both researcher and reader friendly. The researcher has "easy access to the primary data source from the beginning", and the reader is presented with a "personally engaging writing style". (2008:52) Moreover, she claims, auto-ethnographers not only reveal themselves vis a vis self and others, but can transform both themselves and their readers in the process. (2008:52-3)

For Carolyn Ellis and Arthur Bochner, this provides "autobiographies that self-consciously explore the interplay of the introspective, personally engaged self with cultural descriptions mediated through language, history and ethnographic explanation" (2000:742.)

\subsection{The Personal Narrative and/as Knowledge within the Academy}

Within the social sciences, as within the sciences, the personal narrative was not so long ago seen as having: “...failed to qualify as knowledge because it was neither a set of logical propositions nor the product of scientific or quasi-scientific method-therefore, regrettably, it could have no real place in social science" (Stivers 1993:408) Camilla Stivers describes traditional social sciences methodologies as seeing social reality as "out there" and "waiting to be revealed by hypothesis testing, controlled (unbiased) observation, and the replication of previous research results; and that by using the prescribed methodology, social science arrives at Truth, which consists of lawlike generalizations..." (408)

Today, such a search for Truth is generally considered to be untenable. Even within the hard sciences, there is an admission of the place of the imagination. Michael Welland, for example, has written a book about "Sand: a journey through science and the imagination". (2010) Welland brings into his scientific models and descriptions the mythic stories about sand as well as its metaphorical power. In doing so he brings together the power of the imagination and narrative methodology with that of scientific observation and scientific methodology. This is 
well illustrated by his story about sand forensics and Cleopatra's Beach off the coast of Turkey:

The story is that Mark Antony shipped barge loads of sand to the island to create this stretch of beach for his lover. There are no other beaches like this on the island, made, as it is, of exotic creamy white ooliths. Modern analysis has shown that sand of Cleopatra's Beach) is identical to that forming beaches of Alexandria on the Egyptian coast; it probably took Mark Antony around sixteen Roman barges to deliver his exotic gift. (2010:20)

According with Welland's descriptions of analogous knowledge, (1010:28-29), Helen De Cruz and Johan De Smedt argue that creativity is the structured imagination. They concentrate upon "analogical reasoning, our ability to understand new observations or concepts by mapping existing domains onto them" (2009:33) I take this to mean that scientific studies rely upon personal experiences and narratives. De Cruz and De Smedt are interested not so much in what science does, but in how understanding this is brought about. They assert that "current studies suggest that scientists mainly work within the bounds of their conceptual structures...most scientific progress takes place in mental hops, rather than leaps." (34-5) Throughout their paper they posit that "scientific creativity draws on the same cognitive resources as other types of creativity: existing conceptual structures constrain scientists in their creative process..." (43) Such constraints argue against the use of the imagination, of narrativity and of what I have called "the subjective academic narrative" (Arnold 2010). In doing so they miss out on the invaluable attributes and multiple nuances of imbuing scientific methodology with qualitative as well as quantitative attributes.

Could it be that such small incremental "hops" occur because of what Lorraine Daston calls "fear and loathing of the imagination in science" (2005:16)? This, she says, leads scientists to be "as methodical (and as plodding) as accountants". In opposition to such a commonly held error, she acknowledges that "first rate science requires imagination" and this leads her to "explore how and why large portions of the educated public-and many working scientists-think otherwise, systematically opposing imagination to science." (17) Her narrative is in looking at how the historical influence of the enlightenment placed the imagination and scientific knowledge in 2 opposing camps. She says that the "polarisation of the personae of artist and scientist" resulted in the "migration of the imagination to the artistic pole." (17) So emotions embedded in personal imagination became the subject of fiction and such human weakness and scientific reality were placed in stark contrast. The subjective narrative of self and self as data had no role to play in objective science and this eventually became the measuring stick for all academic knowledge.

Acceptance of the narrative of self within the academic community shows a movement towards bridging the isolation from the imagination and the self-narrative performed by the history and philosophy of science over the last 3 centuries. Depersonalising all scientific reports, for example, has moved towards an acknowledgement and sometimes an acceptance, albeit reluctant, of the self as data. This is not yet totally accepted, however, even in the social sciences much less the sciences.

\section{A Feminist View}

Feminism, with its aversion to patriarchal positivist interpretations of what constitutes objectivity and truth, has had an influence upon this trajectory of the imagination and the narrative of self as an accepted and even acceptable aspect of knowledge. Marcel Stoetzler and Nira Yuval-Davis see the faculty of imagination as shaped and conditioned by cultural meta-narratives whilst at the same time asserting that such "situated imagination...transforms, challenges and supersedes both existing knowledge and social reality". (315) For them, this provides a position between "feminist empiricists" and feminists who completely reject the notion of scientific methodologies that are really a "legitimization of a hegemonic masculinist positioning" (315) Situating the imagination in this way does give it a credibility as an inherent and unarguable aspect of science and scientific methodologies.

Reading the traditional discourse of academia as arising from a patriarchal text based on Enlightenment constructions, Jane Gallop proposes a feminist anecdotal theory that calls for opening up textuality and discourse to critical ideas and analyses that seek to be ongoing rather than definitive. (Gallop 2002: 164.) Gallop proposes that "anecdotal theory" is a feminist activity that enables non-patriarchal ways of thinking and doing academic work. It aims to "tie theorizing to lived experience... anecdotal theory must be...the juncture where theory finds itself compelled -against its will, against its projects- to think where it has been forced to think." (Gallop 2002:15) Indeed, Gallop forces us to consider theory itself as an act of power that disempowers others.

The black American lesbian poet belle hooks agrees: "I am constantly amazed at how difficult it is to cross borders in this white supremacist, capitalist, patriarchal society." (2006:6) It is not, she says, an act of will but social privilege that enables such border crossing; it relies upon material, educational and cultural advantage that privileges individuals. Her aim is to establish how borders can be crossed by others (the "non-us" of "them and 
us"?) who enact multicultural and colonized backgrounds of repression so that there is freedom of movement available to all who desire to enact it. So fiercely does she believe in this that she refuses to privilege capital letters in her name.

\section{Conclusion}

The postmodernist challenge to scientific certainties and detached anterior positions in knowledge manufacture has led to the dispersal of certainties within knowledge production in the academy. Strongly influenced by Derrida's notion of deconstruction, this challenge to the Enlightenment influenced methodologies can be seen as enriching the construction of knowledge rather than diminishing it as somehow mere

The narrative of self inevitably leads to mining oneself as data. That this occurs within the academy means a shift in recognition of what makes knowledge and, emphatically, who is the storyteller in that process. It also means that the self recognises that the subjective story is not stand-alone: others are inevitably involved. Without re-visiting the tired debate (Sale et al 2002), narratives being accepted as knowledge within the academy leads us to a bridge across (and even within) the qualitative/quantitative divide that for me is a very important pathway.

In this paper, I have explored some aspects of how the dynamism of the personal prism provides the academy with a rich data base for knowledge about many aspects of the subjective academic narrative. In doing so I have discoursed upon the exploration of self as an inevitable attribute to knowledge to show how self-reflection, observation and analysis is important to the academy and have both proposed and practised my own methodology of the "subjective academic narrative".

\section{References}

Arnold, J. (2010). What do university teachers do all day (and often into the night)? Journal of University Teaching and Practice. Vol. 7. [Online] Available: http://ro.uow.edu.jutlp.vol7/iss1/2 (September 6, 2011)

Arnold, J. (2010). The liminal and apophatic voice of the writer in/as autobiography: a subjective academic narrative, 14 (1). [Online] Available: http://www.textjournal.com.au/april10/content.htm (June 21, 2011)

Arnold. J. (1994). Postmodernism, Feminism and Education. Unpublished PHD thesis. Deakin University. Australia.

Barthes,R. (1977). Image-Music-Text. Fontana Collins, London.

Boote, D.N., \& Beile, P. (2005). Scholars before Researchers: On the centrality of the dissertation literature review in research preparation. Educational Researcher, 34(6), 3-15.

Bourgois, P (2002). Ethnography's troubles and the reproduction of academic habitus. In Qualitative Studies in education, 15(4), 417-420.

Bryant, J., \& Lasky, B. (2007). A researcher's tale: dealing with epistemological divergence. In Qualitative Research in Organizations and Management: An International Journal, 2(3), 181-93. Emerald Publishing Group. Northampton. U.K.

Bullough, R.V., \& Pinnegar, S. (2001). Guidelines for quality in autobiographical forms of self-study research. Educational Reviewer, 30(3), 13-21.

Chang, H. (2008). Autoethnography as a method. Left Coast Press. Ca. USA.

Cixous, H. (1991). ed. D. Jenson. “Coming to writing” and other essays. Harvard University Press. Cam. Mass.

Dahl, T. (2004). Textual metadiscourse in research articles: a marker of national culture or of academic discipline? Journal of Pragmatics 36, 1807-1825. http://dx.doi.org/10.1016/j.pragma.2004.05.004

Daston, L. (2005). Fear and loathing of the imagination in science, Daedalus Falls.

De Cruz , H., \& De Smedt, J. (2009). Science as structured imagination. Journal of Creative Behaviour 44 (1), $29-44$.

Deleuze, G., \& Guattari, F. (1981). Rhizome, Power and Desire, Diagrams of the Social. I\&C Spring no.8. Smythe \& Murray.

Denzin \& Y.S. Lincoln (2011). Handbook of Qualitative Research (2 ${ }^{\text {nd }}$ edition) Pp733-768. Thousand Oaks, Ca. Sage.

Derrida, J. (1978). Structure Sign and play in the human sciences. In Writing and Difference. Routledge and Kegan Paul. London.

Derrida, J. (1980). The law of genre Critical Enquiry. Vol.7. No.1 Autumn. 
Ellis, C., \& Bochner, A.P. (2000) Autoethnography, personal narrative, and personal reflexivity. In N.K.

Gallop, J. (2002). Anecdotal Theory. Duke University Press. U.S.A.

Holt, N. (2003). Representation, legitimisation \& autoethnography: An autoethnographic writing story. International Journal of Qualitative Methods. University of Alberta. Pp18-28

Kamler, B., \& Thomson, P. (2004). Driven to abstraction: doctoral supervision and writing pedagogies. Teaching in Higher Education, 9(2), 195-209. http://dx.doi.org/10.1080/1356251042000195358

Laureiro, A. (2000). The ethics of autobiography. Vanderbilt University Press.

Midgely, M. (2004). The myths we live by. Routledge Oxon and New York.

Myerhoff, B. (1992). Remembered lives: the work of ritual, storytelling and growing older. University of Michigan Press, Ann Arbor. U.S.A.

Northedge, A. (2003a). Enabling participation in academic discourse. Teaching in Higher Education, 2(1), 169-180. http://dx.doi.org/10.1080/1356251032000052429

Sale, J. Lohfeld, L., \& Brazil, K. (2002). Revisiting the Quantitative-Qualititative Debate: Implications for Mixed-Methods Research. Quality \& Quantity, 36, 43-53.

Stivers, C. (1993). Reflections on the role of personal narrative in social science. Signs, 18 (2), $408-425$. http://dx.doi.org/10.1086/494800

Smythe, W., \& Murray. M. (2000). Owning the story: Ethical considerations in narrative research. Ethics and Behavior, 10(4), 311-336. http://dx.doi.org/10.1207/S15327019EB1004_1

Stoetzler, M., \& Yuval-Davis, N. (2002). Standpoint theory, situated knowledge and the situated imagination. Feminist Theory. Sage. London.

Spivak, G. (2002). A critique of Ppostcolonial Reason. Harvard University Press. Cambridge. Mass. U.S.A.

Swartz, R. (2009). Affirming the "S" in HBSE through the socio-cultural discourses of Lev Vygotsky, Barbara Myerhoff, Jerome Bruner, and Ken Gergen. Journal of Human Behaviour in the Social Environment. 19 (7), 787-804. http://dx.doi.org/10.1080/10911350903041545

Ulmer, G (1989). Teletheory: Grammatology in the Age of Video. Routledge, NY.

Welland, M. (2010). Sand: a journey through science and the imagination. Oxford University Press. Oxford. 